\title{
Comparison of Tape Drip Irrigation and Furrow Irrigation Systems on Base of Water Use Efficiency and Yield of Potato in West of Iran
}

\author{
Fakhrodin Ghasemi-Sahebi ${ }^{1}$, Farid Ejlali ${ }^{2}$, Mehdi Ramezani $^{3} \&$ Iman Pourkhiz ${ }^{4}$ \\ ${ }^{1}$ Department of Irrigation and Drainage, University, Kermanshah Branch, Kermanshah, Iran \\ ${ }^{2}$ Membership of Tehran payam-e- noor University, Iran \\ ${ }^{3}$ Young Researcher Club Member Talent, Department of Agronomy, Science and Research Branch, Islamic Azad \\ University, Tehran, Iran \\ 4 Young Researcher Club Member, Department of Agricultural Management, Islamic Azad University, \\ Qaemshahr Branch, Qaemshahr, Iran \\ Correspondence: Mehdi Ramezani, Young Researcher Club Member Talent, Department of Agronomy, Science \\ and Research Branch, Islamic Azad University, Tehran, Iran. E-mail: mehdiramezani1979@yahoo.com
}

Received: May 14, 2012 Accepted: May 31, 2012 Online Published: November 29, 2012

doi:10.5539/ijb.v5n1p52 URL: http://dx.doi.org/10.5539/ijb.v5n1p52

\begin{abstract}
Potato is a major crop of Kermanshah province but shortage of water is important its production. To investigate yield and water use efficiency (WUE) of potato with trickle (T-Tape) and furrow irrigations, an experiment was performed in Kermanshah agriculture university research farm in 2007. The experiment was in complete randomized blocks design with 3 levels of irrigation-water amount $(50 \%, 75 \%$ and $100 \%$ of cumulative evaporation from Class A pan) and irrigation methods (tape and furrow irrigations) with 3 replications. The results indicated that regardless to irrigation method, the maximum yield of potato (34.455 ton/ha) was achieved in irrigation water treatment of $100 \%$ and the minimum yield of potato $(19.168 \mathrm{ton} / \mathrm{ha})$ was achieved in irrigation water treatment of $50 \%$. The effect of irrigation method on WUE was significant $(\mathrm{P}<0.01)$. The highest WUE $(3.93 \mathrm{~kg} / \mathrm{m} 3)$ was belonged to $50 \%$ tape irrigation and the lowest WUE $(1.2 \mathrm{~kg} / \mathrm{m} 3)$ was belonged to furrow irrigation. Tape irrigation caused an increase of $66 \%$ in WUE as compared to furrow irrigation. The difference in WUE between $50 \%, 75 \%$ and $100 \%$ irrigation treatment was not significant. The least percent of tubers smaller than $35 \mathrm{~mm}(26.42 \%)$ was obtained in tape irrigation method with $50 \%$ irrigation-water amount and the highest percent of tubers smaller than $35 \mathrm{~mm}(37.99 \%)$ was obtained in furrow irrigation method. The highest amount of tuber production $(37.17 \%$ ) in marketable size (tubers larger than $55 \mathrm{~mm}$ ) was obtained in tape irrigation method with $100 \%$ irrigation-water amount. As the irrigation water increased, percentage of tubers larger than $55 \mathrm{~mm}$ increased. The effect of irrigation method on dry matter was not significant, but with reduction of irrigation water, the specific gravity of tubers of potato was decreased. It is suggested to use tape irrigation method, with irrigation water amount of $100 \%$ for producing potato.
\end{abstract}

Keywords: type of irrigation, furrow irrigation, potatoes, dry

\section{Introduction}

Research has shown that potato plants are very sensitive to drought stress. Adverse effects of stress on growth and yield of potato plant growth stage, the gland is enlarged. At this stage, drought stress strongly influences the performance and product quality. Last growth stage of potato plants, is maturity (Almekinfers, 1991).

Gland, all existing simultaneously in one plant will not begin to accumulate dry matter. The differences caused by time and location of the tumor on the thyroid gland size and weight of the plant is to be Market-friendly, but the average tumor weight is less, reduced (Haverkort et al., 1990; Elizabet, 1992).

Yuan et al. (2003) effects of different irrigation regimes on potato crop growth in drip irrigation was investigated. The amount of irrigation water equal to $125,100,75,50$ and 25 percent of water evaporates from the surface of Chinese pan evaporation (pan diameter $0.2 \mathrm{~m}$ ) was considered. Plant height, the amount of biomass, the whole lump of fresh products and Bazarpsnd glands (greater than $85 \mathrm{~g}$ ) increased with increasing amount of irrigation water. Plant height and total product in the treatment of tumors close to $125 \%$ of evaporation from pan evaporation treatment was $100 \%$. Irrigation water to increase the number of tubers did not increase, but will also 
increase the average tumor weight. Irrigation water quantity and quality of tubers but reduced the tumor increases.

Shock et al. (1993) and Nadler and Heuer (1995) stated that reducing irrigation water, reduced tumor weight and reducing sugar level increases. This reduction in specific gravity of tubers in response to irrigation during the growing season is long.

The purpose of this study the effect of different amounts of irrigation water and irrigation methods on yield and groove type, yield components and properties of potato (dry matter and specific gravity) is.

\section{Materials and Methods}

Tested in the spring of 2007 in Kermanshah Agricultural Research Station in order to compare the performance of potatoes (variety Agria), furrow irrigation methods and types of performances. Silt clay soil with 54\% clay and silt was $42 \%$. Salinity of soil saturation extract ds / m 1.2 and soil PH 7.3, salinity of ds / $\mathrm{m} 1$ and PH of 7.1 was measured. Tested in a randomized complete block design in three replications. Row distance $75 \mathrm{~cm}$ and 30 $\mathrm{cm}$ plant spacing and planting depth of $10 \mathrm{~cm}$ and a length of $13 \mathrm{~m}$. Each treatment was planted with four rows. The drip irrigation emitters within the bladder tube type, was $30 \mathrm{~cm}$. In this experiment, about 500 square meters of land with three replicates and based on a randomized complete block design was organized. The amount of irrigation water was considered as the main factor. 2 days away from drip irrigation and irrigation levels were 5 to 7 days. For this purpose, all the organs in the laboratory, isolated and dried in oven $70^{\circ} \mathrm{C}$ for 48 hours and then was weighed. Understanding plant response to treatments applied to the calculation of indicators, drawn and analyzed. SAS software was used for statistical analysis and was compared to Duncan.Measure and control the amount of irrigation water input to each plot in each treatment was done by volumetric meters. Gross irrigation requirements for the methods used in calculating the efficiency of the gully for 40 percent of the plots as runoff water was removed. Potato plant growth during the months of May, in October 1386 in the amount of evaporation from basin class A weather station located in Kermanshah city airport were measured. Given the location and circumstances surrounding the evaporation basin, basin coefficient of 0.8 was determined. For obtainfactor for the plant, the method was presented in the publication FAO24. This course is divided into 4 stages of plant growth. Crop coefficient for potato crop in this region in early, middle and end, respectively, 0.5 , 1.15 and 0.6 were determined.

To calculate the crop water requirements of class A evaporation pan data for evaporation from the airport weather station that was located near the Faculty of Agriculture, was used. The potential evapotranspiration was calculated from the following equation:

$$
E T=K_{p} . E_{\text {pan }}
$$

pan (1) Where: $E T=$ evapotranspiration in millimeters between the two irrigation. Pan evaporation coefficient $K$ $p=E$ pan $=$ pan evaporation of water between every two consecutive terms of $\mathrm{mm}$ ). The treated water is then multiplied by factors related to water level treatments $(50,75$ and 100 percent) in evapotranspiration was calculated from a relationship.

All agricultural operations like weeding, fertilizing and spraying practices and require the samefield experiment was conducted in each unit. At the end of the growing season of each experimental plot was $6 \mathrm{~m}$ length of two adjacent middle and potatoes were harvested. The smaller tumor size in groups of 35, 35 and 55 and older were divided into $55 \mathrm{~mm}$.

For product quality testing Such as measuring specific gravity and percent dry matter samples taken from each treatment and was transported to the laboratory.

Table 1. Soil chemical features

\begin{tabular}{|c|c|c|c|c|c|c|c|c|c|c|c|}
\hline $\begin{array}{l}\text { Type } \\
\text { of soil } \\
\text { texture }\end{array}$ & $\begin{array}{l}\text { Clay } \\
\%\end{array}$ & $\begin{array}{l}\text { Silt } \\
\%\end{array}$ & $\begin{array}{l}\text { Sand } \\
\%\end{array}$ & $\begin{array}{l}\mathrm{Zn} \\
\mathrm{Mg} / \mathrm{kg}\end{array}$ & $\begin{array}{l}\mathrm{Fe} \\
\mathrm{Mg} / \mathrm{kg}\end{array}$ & $\begin{array}{l}\mathrm{Mn} \\
\mathrm{Mg} / \mathrm{kg}\end{array}$ & $\begin{array}{l}\text { Carbon } \\
\%\end{array}$ & $\begin{array}{l}\text { PPM } \\
\text { Absorbable } \\
\text { potassium }\end{array}$ & $\begin{array}{l}\text { PPM } \\
\text { Absorbable } \\
\text { phosphor }\end{array}$ & $\begin{array}{l}\mathrm{EC} \\
\mathrm{ds} / \mathrm{m}\end{array}$ & $\mathrm{pH}$ \\
\hline $\begin{array}{l}\text { Silty } \\
\text { clay }\end{array}$ & 45 & 42.3 & 3.7 & 1.36 & 11.9 & 7.8 & 1.38 & 440 & 26 & 1.2 & 7.3 \\
\hline
\end{tabular}


Table 2. Water chemical features

\begin{tabular}{|c|c|c|c|c|c|c|c|c|c|c|c|c|}
\hline SAR & $\begin{array}{l}\text { Percent } \\
\text { of } \\
\text { soluble } \\
\text { sodium }\end{array}$ & $\begin{array}{l}\text { Sum of } \\
\text { catiuns }\end{array}$ & $\mathrm{Na}+$ & $\begin{array}{l}\mathrm{Mg}++ \\
+ \\
\mathrm{Ca}++\end{array}$ & $\begin{array}{l}\text { Sum } \\
\text { of } \\
\text { aniuns }\end{array}$ & $\begin{array}{l}\text { SO4-- } \\
\text { Meq/1 }\end{array}$ & $\begin{array}{l}\text { CL- } \\
\text { Meq/1 }\end{array}$ & $\begin{array}{l}\mathrm{HCO3-} \\
\mathrm{Meq} / 1\end{array}$ & $\begin{array}{l}-- \\
\mathrm{CO} 3 \\
\mathrm{Meq} / 1\end{array}$ & $\mathrm{pH}$ & $\begin{array}{l}\text { TDS } \\
\mathrm{Mg} / \mathrm{lit}\end{array}$ & EC \\
\hline 0.54 & 11.7 & 9.23 & 1.08 & 8.15 & 9.23 & 1.18 & 1.9 & 6.15 & 0.0 & 7.1 & 640 & 1000 \\
\hline
\end{tabular}

\subsection{Use Efficiency}

Application efficiency in furrow irrigationUsed to calculate the efficiency of the samples before and after irrigation water is used in deep root development. Depth development of roots sampled from soil by digging a hole to reach 5 times with water.

Table 3. Applied yield in furrow irrigation

\begin{tabular}{llllll}
\hline $\begin{array}{l}\text { Time of } \\
\text { irrigation }\end{array}$ & $\begin{array}{l}\text { Soil humidity } \\
\text { Average } \\
\text { before } \\
\text { irrigation } \\
\%\end{array}$ & $\begin{array}{l}\text { Soil humidity } \\
\text { Average after } \\
\text { irrigation } \\
\%\end{array}$ & $\begin{array}{l}\text { Root extension } \\
\text { depth average } \\
\text { (Centimeter) }\end{array}$ & $\begin{array}{l}\text { Depth of water in } \\
\text { furrow } \\
\text { (Centimeter) }\end{array}$ & $\begin{array}{l}\text { Applie } \\
\text { d yield } \\
\%\end{array}$ \\
\hline 1 & 14.9 & 24.7 & 20 & 6.14 & 49.48 \\
2 & 14.8 & 23.4 & 20 & 6.51 & 40.95 \\
3 & 14.8 & 24.6 & 20 & 7.9 & 38.45 \\
4 & 15.2 & 24.1 & 20 & 8.09 & 34.10 \\
5 & 15.1 & 25.1 & 20 & 7.42 & 41.78 \\
\hline
\end{tabular}

As Table 3 can be used respectively at 34.1 and maximum efficiency is 49.48 percent. Major cause of low irrigation efficiency, losses in surface runoff is.

\subsection{Use Efficiency in Irrigation Type}

The first type of method used to measure the efficiency of uniform and then calculate the coefficient of TR, the efficiency was achieved. The uniformity coefficient, flow rate 36 outputs (4 outputs each type, 3 sub-pipes of 3 replicates) were also measured. Uniformity coefficient of 0.89 and efficiency with regard to application of $0.9=$ $\mathrm{TR}, 0.80$, respectively.

Table 4. Applied yield in tape drip irrigation

\begin{tabular}{lllll}
\hline Ea & TR & EU & $\begin{array}{l}\text { qa } \\
\text { Liter per hour }\end{array}$ & $\begin{array}{l}\text { qn } \\
\text { Liter per hour }\end{array}$ \\
\hline 0.80 & 0.90 & 0.89 & 1.222 & 1.083 \\
\hline
\end{tabular}

$\mathrm{qn}=$ average flow of a quarter-liter $\mathrm{h}$;

$\mathrm{qa}=$ average flow rate measured by output, liter per hour;

$\mathrm{EU}=$ uniformity based on measurements of water leaving the farm, the percentage;

$\mathrm{TR}=$ the ratio of transpiration to;

$\mathrm{Ea}=$ Application efficiency.

Specific gravity divided by the weight of tumor samples on the sample size was achieved. For tuber dry matter are randomly selected and their skin was shaved and the mixture was chopped very fine. 
About 5 grams of this mixture in the Chinese plant in Avon $105 \mathrm{C}$ to constant weight had been dropped and 6 hours Airflow in the oven until constant weight was reached. The Chinese plant was cooled in desiccator and weigh again, and dry matter percentage was calculated (Van Heemst, 1986).

Volume of water used in irrigation water in different treatments (Table 5) are presented.

Table 5. Total volume of water the plant during each irrigation methods

\begin{tabular}{lllll}
\hline Treatment & $\begin{array}{l}\text { 00\% Water } \\
\text { requirement }\end{array}$ & $75 \%$ Water requirement & 50\%Water requirement & Furrow irrigation \\
\hline $\begin{array}{l}\text { Total water } \\
\text { (per hectarem) }\end{array}$ & 9749.62 & 7312.21 & 4874.81 & 21357.20 \\
\hline
\end{tabular}

Comparison of moisture in the onions under drip irrigation tape is said treatments to obtain samples. Weight around the stack of potatoes in three successive irrigation. Onions compared to moisture and humidity distribution. Irrigation treatments listed in the Surfer software was used for the graphs in Figure 1 is shown.
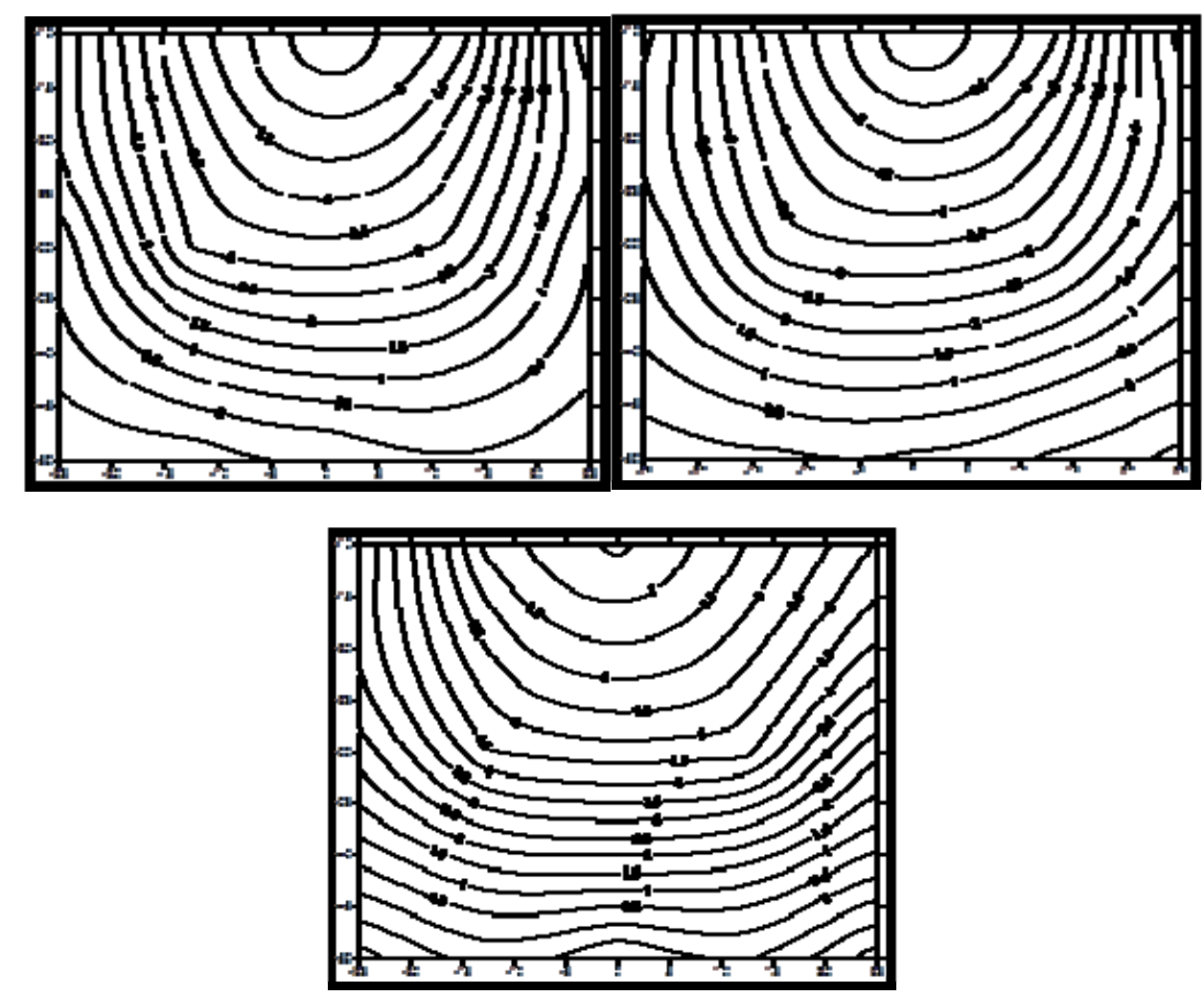

Figure 1. Chart moisture in irrigated onions first - (a) treatment by $50 \%$, (b) treatment by $75 \%$ and (c) treated $100 \%$

\section{Results and Discussion}

Moisture curves were plotted the gradient changes, lack of moisture in the bottom three were initially treated with Depth is too high. The lack of moisture in all three treatments in the upper layers of soil andMuch ofis located in the root density, the lower layers and with a greater depthhumidity is low. 
Table 6. Comparison of average performance and efficiency of water use

\begin{tabular}{lll}
\hline Treatment & $\begin{array}{l}\text { Yield } \\
\text { (Ton pre hectare) }\end{array}$ & $\begin{array}{l}\text { Water use efficiency } \\
(\mathrm{kg} / \mathrm{m} 3)\end{array}$ \\
\hline $50 \%$ evaporate from pan & $19.16 \mathrm{c}$ & $3.93 \mathrm{a}$ \\
$75 \%$ evaporate from pan & $25.93 \mathrm{~b}$ & $3.54 \mathrm{a}$ \\
$100 \%$ evaporate from pan1 & $34.45 \mathrm{a}$ & $3.53 \mathrm{a}$ \\
\hline
\end{tabular}

Two types of drip irrigation and crop yield in each groove being separated and were significantly different in Duncan.

Potato yield in drip irrigation method is 100 percent more performance than 8.873 ha. The method has been the product surface. Necessary to maintain moisture in the root zone of plants to absorb nutrients and tumor growth, analysis of water and water use efficiency is of particular importance.

In this test the water in the gully was more than twice as drip irrigation, however, per acre product is much lower.

\subsection{The Tuber Yield}

The amount of irrigation water on the tuber yield was significant at the 1 percent level (Table 7). The lowest 50 percent of the treatment of 19.168 tons per hectare and a maximum of about 100 percent of the 34.455 ha were treated (Table 7). $75 \%$ of surface irrigation treatment and Duncan groups were in a group. This experiment showed that the more water the plant will supply the tumor grows.

Table 7. ANOVA analysis of potato

\begin{tabular}{llll}
\hline Change source & Freedom degree & Yield of plant $(\mathrm{kg})$ & Yield (ton per hac) \\
\hline repetition & 2 & 0.015 & 6.13 \\
treatment & 3 & $0.425^{* *}$ & $354.02^{* *}$ \\
Error & 6 & 0.036 & 27.60 \\
total & 11 & 0.477 & 387.76 \\
Change coefficient & & 8.85 & 8.16 \\
\hline
\end{tabular}

**Indicate a significant effect of experimental treatment is $1 \%$ probability level.

Table 8. compared with an average yield of potatoes

\begin{tabular}{lll}
\hline Treatment & Yield of plant $(\mathrm{kg})$ & Yield (ton per hac) \\
\hline $50 \%$ evaporate from pan & $0.62 \mathrm{c}$ & $\mathrm{c} 19.16$ \\
$75 \%$ evaporate from pan & $0.95 \mathrm{~b}$ & $\mathrm{~b} 25.93$ \\
$100 \%$ evaporate from pan 1 & $1.13 \mathrm{a}$ & $\mathrm{a} 34.45$ \\
Furrow irrigation & $0.82 \mathrm{~b}$ & $\mathrm{~b} 25.58$ \\
\hline
\end{tabular}

The numbers in each column treatments with a common letter are not significantly different according to Duncan test at $5 \%$ level are likely.

\subsection{Tumor Size}

\subsubsection{Percentage of Tubers Smaller than $35 \mathrm{~mm}$}

The amount of irrigation water on the percentage of tubers smaller than $35 \mathrm{~mm}$ were not significant (Table 9). Minimal lesions (26.47\% of tiny glands) in the treatment of 100 percent drop, and most lesions (37.39 percent) was observed in surface irrigation. 


\subsubsection{Glands of $55-35 \mathrm{~mm}$}

The amount of irrigation water on the percentage of tubers smaller than $35 \mathrm{~mm}$ were not significant (Table -9). The classification of tumor size, size $55-35 \mathrm{~mm}$ seed size is considered. If the goal is the production of seed potatoes, seed tuber production of the highest drop of 50 percent ( 47.87 percent) are.

\subsubsection{Percentage of Tubers Larger than $55 \mathrm{~mm}$}

The amount of irrigation water on the percentage of tubers smaller than $35 \mathrm{~mm}$ were not significant (Table -9). Tumors larger than $55 \mathrm{~mm}$ in size are considered edible and Bazarpsnd.

Table 9. Analysis of variance of the groups with tumor sizes smaller than 35, 55-35 and greater than $55 \mathrm{~mm}$

\begin{tabular}{lllll}
\hline Change source & Freedom degree & $\begin{array}{l}\text { Smaller than } \\
35 \mathrm{~mm}\end{array}$ & $\begin{array}{l}\text { Between } \\
35-55 \mathrm{~mm}\end{array}$ & $\begin{array}{l}\text { larger than } \\
35 \mathrm{~mm}\end{array}$ \\
\hline repetition & 2 & 356.94 & 7.87 & 326.44 \\
treatment & 3 & 270.86 & 211.13 & 370.14 \\
Error & 6 & 388.61 & 505.60 & 274.83 \\
total & 11 & 1016.42 & 724.66 & 971.42 \\
$\begin{array}{l}\text { Change } \\
\text { coefficient }\end{array}$ & & 26.26 & 22.31 & 23.981 \\
\hline
\end{tabular}

** Indicate a significant effect of experimental treatment is $1 \%$ probability level.

Table $10.1 \%$ of the mean tumor size in groups smaller than $35,55-35$ and greater than $55 \mathrm{~mm}$

\begin{tabular}{lcll}
\hline Treatment & $\begin{array}{c}\text { Smaller than } \\
35 \mathrm{~mm}\end{array}$ & $\begin{array}{l}\text { Between } \\
35-55 \mathrm{~mm}\end{array}$ & $\begin{array}{l}\text { Larger than } \\
35 \mathrm{~mm}\end{array}$ \\
\hline $50 \%$ evaporate from pan & $26.42 \mathrm{a}$ & $47.87 \mathrm{a}$ & $25.70 \mathrm{ab}$ \\
$75 \%$ evaporate from pan & $31.67 \mathrm{a}$ & $40.45 \mathrm{a}$ & $27.86 \mathrm{ab}$ \\
$100 \%$ evaporate from pan1 & $26.47 \mathrm{a}$ & $36.35 \mathrm{a}$ & $37.17 \mathrm{a}$ \\
Furrow irrigation & $37.99 \mathrm{a}$ & $39.85 \mathrm{a}$ & $22.15 \mathrm{~b}$
\end{tabular}

The numbers in each column treatments with a common letter are not significantly different according to Duncan test at $5 \%$ level are likely.

\subsection{The Number of Main Stems}

The amount of irrigation water on the number of main stems per square meter and the plant was not significant (Table 11). The number of main stems per plant size and physiological age of seed tubers and genetic characteristics of the figure (the number of seed tubers) depends on (Nadler \& Heuer, 1995). Maximum number of main stems per square meter in the treatment of $100 \%$ (25.08), respectively.

\subsection{Total Tuber}

\subsubsection{The Number of Tubers Per Square Meter}

The amount of irrigation water on the tubers was not significant (Table 11). The maximum number of tubers per square meter of treated water by $50 \%$ (35.86) and the minimum number of tubers per square meter of treated water by $75 \%$ (34.06) was obtained. Havrkvrt and colleagues showed a high correlation between the number of tubers is ostolon (Haverkort et al., 1990). 
Table 11. Analysis of variance of main stem and number of tubers

\begin{tabular}{llllll}
\hline Change source & $\begin{array}{l}\text { Freedom } \\
\text { degree }\end{array}$ & $\begin{array}{l}\text { Number of stem } \\
\text { in each plant }\end{array}$ & $\begin{array}{l}\text { Number of } \\
\text { stem in } \mathrm{m}^{2}\end{array}$ & $\begin{array}{l}\text { Number of tuber } \\
\text { in each plant }\end{array}$ & $\begin{array}{l}\text { Number of } \\
\text { tuber in } \mathrm{m}^{2}\end{array}$ \\
\hline repetition & 2 & 2.50 & 54.62 & 2.23 & 45.93 \\
treatment & 3 & 2.56 & 63.04 & 1.86 & 44.93 \\
Error & 6 & 1.63 & 51.50 & 10.32 & 260.35 \\
total & 11 & 6.70 & 169.17 & 14.42 & 351.22 \\
Change coefficient & & 12.25 & 13.73 & 19.29 & 19.30 \\
\hline
\end{tabular}

**Indicate a significant effect of experimental treatment is $1 \%$ probability level.

Table 12. Comparison of average number of main stems and tubers

\begin{tabular}{lllll}
\hline Treatment & $\begin{array}{l}\text { Number of stem } \\
\text { in each plant }\end{array}$ & $\begin{array}{l}\text { Number of } \\
\text { stem in } \mathrm{m}^{2}\end{array}$ & $\begin{array}{l}\text { Number of tuber } \\
\text { in each plant }\end{array}$ & $\begin{array}{l}\text { Number of tuber } \\
\text { in } \mathrm{m}^{2}\end{array}$ \\
\hline $50 \%$ evaporate from pan & $4.03 \mathrm{a}$ & $19.75 \mathrm{a}$ & $7.09 \mathrm{a}$ & $35.86 \mathrm{a}$ \\
$75 \%$ evaporate from pan & $4.19 \mathrm{ab}$ & $21.29 \mathrm{a}$ & $6.19 \mathrm{a}$ & $31.06 \mathrm{a}$ \\
$100 \%$ evaporate from pan1 & $5.02 \mathrm{a}$ & $25.08 \mathrm{a}$ & $6.71 \mathrm{a}$ & $33.90 \mathrm{a}$ \\
Furrow irrigation & $3.80 \mathrm{~b}$ & $19.21 \mathrm{a}$ & $7.19 \mathrm{a}$ & $35.71 \mathrm{a}$ \\
\hline
\end{tabular}

The numbers in each column treatments with a common letter are not significantly different according to Duncan test at $5 \%$ level are likely.

\subsubsection{Percentage of Dry Matter}

The amount of irrigation water on dry matter was not significant (Table 13). The percentage of dry matter decreased with increasing amount of irrigation water. Mohammadi Fayznya and grace and Fayznya Mousavi said that increasing the amount of irrigation, the percentage increase in dry matter (Elizabet, 1992; Haverkort et al., 1990).

\subsection{Gland Density}

The amount of irrigation water on tuber specific gravity was significant at the one percent level. Maximum density (1.11 grams per cubic centimeter), the type of treatment was $100 \%$. Irrigation water increased with increasing specific gravity of tubers that are consistent with studies of Yuan et al.

Table 13. Analysis of variance and the density of dry matter

\begin{tabular}{llll}
\hline Change source & Freedom degree & $\begin{array}{l}\text { Density } \\
(\mathrm{g} / \mathrm{cm} 3)\end{array}$ & $\begin{array}{l}\text { Dry matter } \\
\%\end{array}$ \\
\hline repetition & 2 & 0.000026 & 8.05 \\
treatment & 3 & $0.001296^{* *}$ & 13.78 \\
Error & 6 & 0.000062 & 12.58 \\
total & 11 & 0.001384 & 34.43 \\
Change coefficient & & 0.293083 & 6.97 \\
\hline
\end{tabular}

**Indicate a significant effect of experimental treatment is $1 \%$ probability level. 
Table 14. Comparison of average density and dry matter

\begin{tabular}{lll}
\hline Treatment & $\begin{array}{l}\text { Density } \\
(\mathrm{g} / \mathrm{cm} 3)\end{array}$ & $\begin{array}{l}\text { Dry matter } \\
\%\end{array}$ \\
\hline $50 \%$ evaporate from pan & $1.085 \mathrm{~d}$ & $22.08 \mathrm{a}$ \\
$75 \%$ evaporate from pan & $1.102 \mathrm{~b}$ & $21.51 \mathrm{a}$ \\
$100 \%$ evaporate from pan 1 & $1.113 \mathrm{a}$ & $19.46 \mathrm{a}$ \\
Furrow irrigation & $1.093 \mathrm{c}$ & $19.99 \mathrm{a}$
\end{tabular}

The numbers in each column treatments with a common letter are not significantly different according to Duncan test at $5 \%$ level are likely.

The type of irrigation compared with furrow irrigation, potato yield, water use efficiency and the percentage was higher in tumors larger than $55 \mathrm{~mm}$ seed is a factor of 0.75 is recommended.

In order to understand plant responses to treatments, growth was calculated, plotted and analyzed. In general, both surface and drip irrigation methods, parameters, leaf weight, stem weight, shoot dry weight, root weight and root dry weight is affected. In the fourth column from left to right, respectively, showed $50 \%, 75 \%, 100 \%$ irrigation treatment is superficial.But on the dry weight of leaves, number of stems per plant, number of tubers per plant, number of tubers larger than $35 \mathrm{~mm}$ and total weight of the gland has no effect. The effect of harvest date, except for number of stems

For this purpose, all the organs in the laboratory, isolated and dried in oven $70^{\circ} \mathrm{C}$ for 48 hours and then was weighed. In order to understand plant responses to treatments, growth was calculated, plotted and analyzed. In general, both surface and drip irrigation methods, parameters, leaf weight, stem weight, shoot dry weight, root weight and root dry weight is affected. In the fourth column from left to right, respectively, showed $50 \%, 75 \%$, $100 \%$ irrigation treatment is superficial.But on the dry weight of leaves, number of stems per plant, number of tubers per plant, number of tubers larger than $35 \mathrm{~mm}$ and total weight of the gland has no effect. The effect of harvest date, except for number of stems per plant and number of tubers per plant was significant. With the view of some models, the growth characteristics include: Leaf weight ratio (LWR), Tuber dry matter (TDM), Leaf dry matter (LDM) and Total dry matter (TDM) during the growing period and calculated on the basis They plant growth were analyzed.

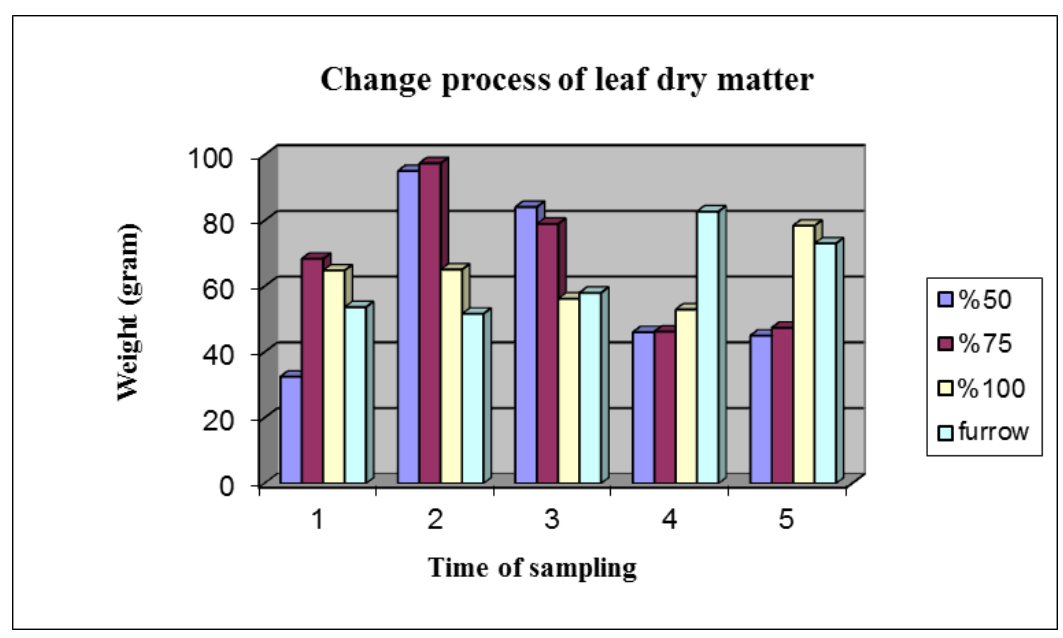

Figure 1. The changes process of traits 


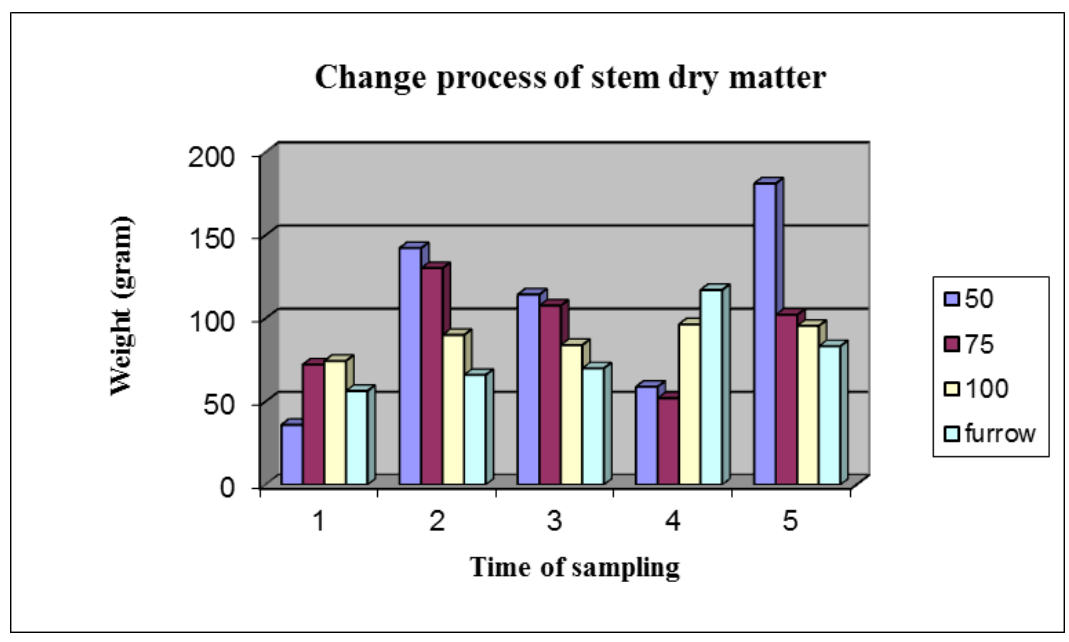

Figure 2. The changes process of traits

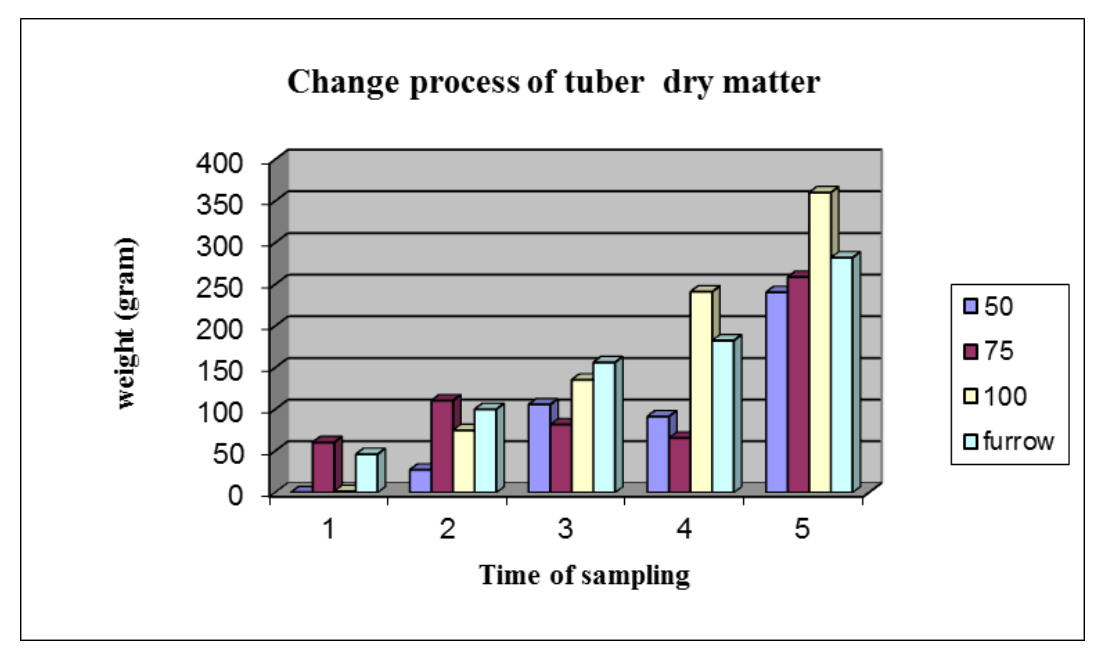

Figure 3. The changes process of traits

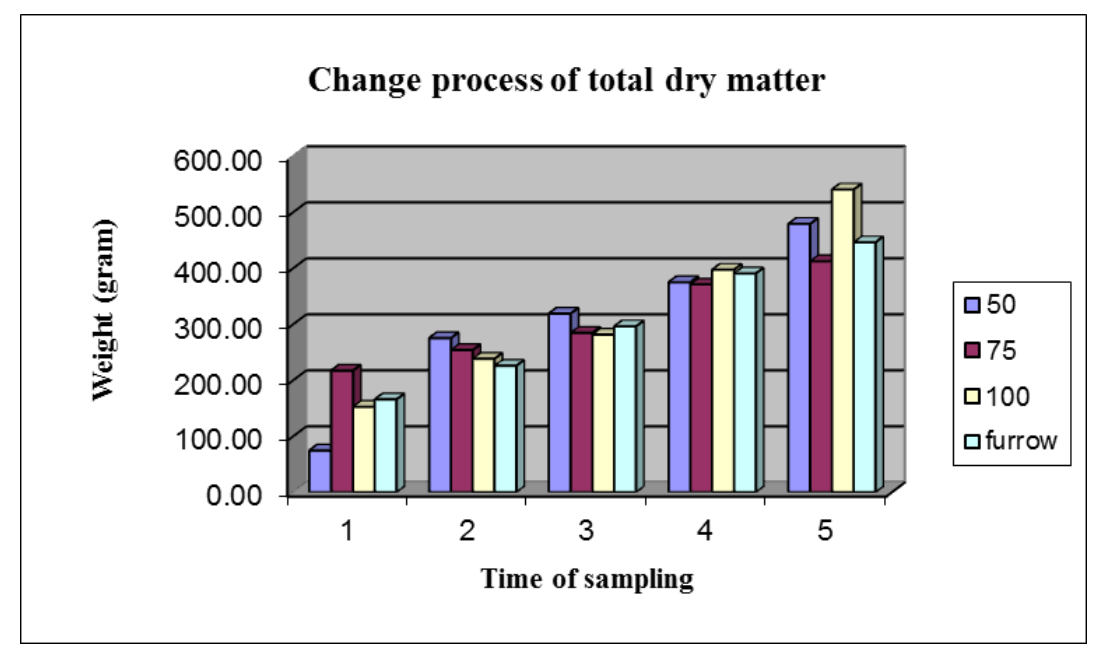

Figure 4. The changes process of traits 


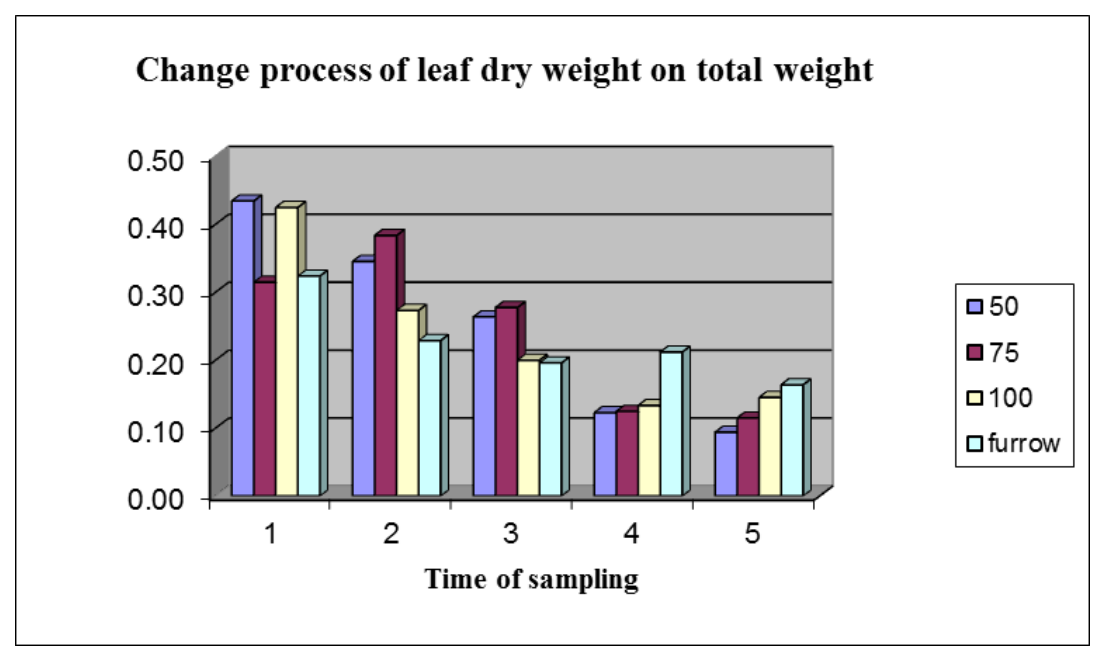

Figure 5. The changes process of traits

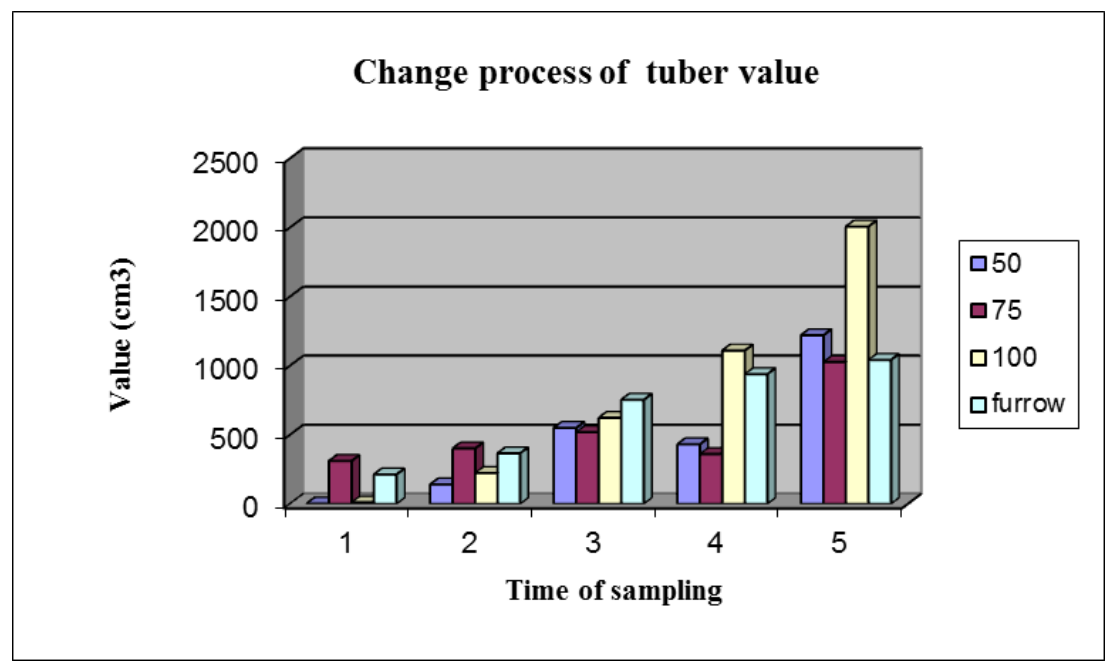

Figure 6 . The changes process of traits

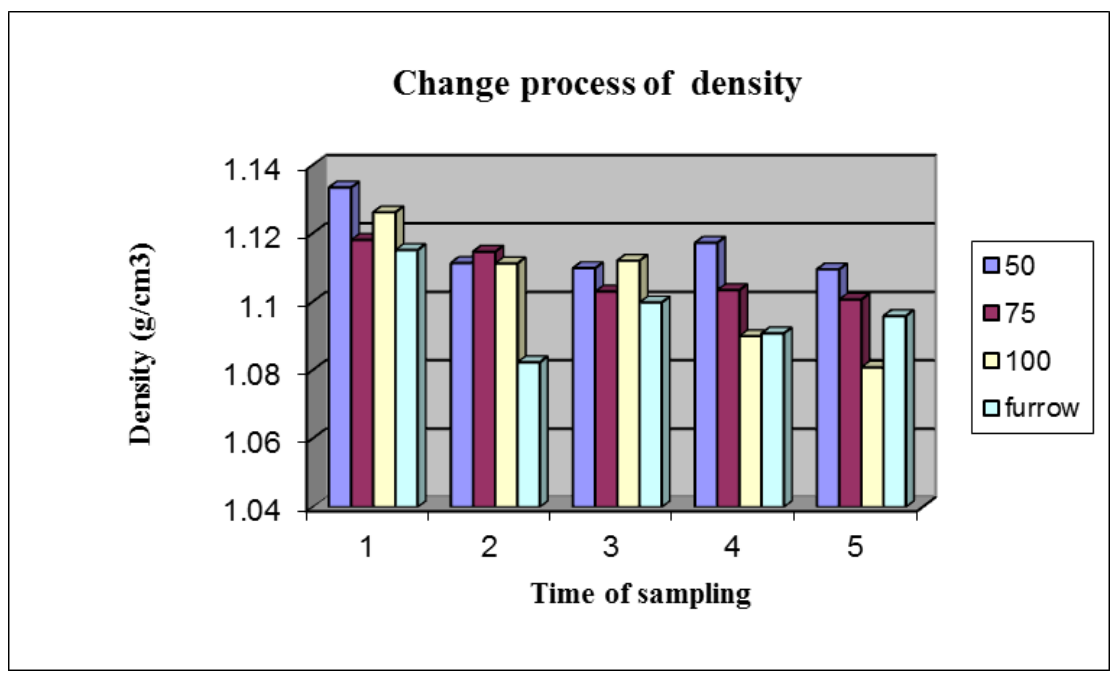

Figure 7 . The changes process of traits 


\section{References}

Allen, E. J. (1972). The effect of row width on the yield of three potato varieties. J. Agric. Sci. camb., 79, 315-321.

Almekinfers, C. J. M. (1991). Flowering and true seed production in potato (Solanum tuberosum L.): Effect of stem density and pruning at lateral stems. J. Potato Res., 34, 379-388. http://dx.doi.org/10.1007/BF02360574

Elizabet, G. C. (1992). Structure and development of potato plant. In P. M. Harris (Ed), The potato crop: Scientific basis for improvement (pp. 65-146). London: Chapman and Hall.

Haverkort, A. J., De Wart, M. V., \& Bodlaender, K. B. A. (1990). Inter-relationship of the number of initial sprouts, stems, stolons and tubers per potato plant. Potato Res., 33, 269-274. http://dx.doi.org/10.1007/BF02358456

Nadler, A., \& Heuer, B. (1995). Effect of saline irrigation and water deficit on tuber quality. Potato Res., 38, 119-123. http://dx.doi.org/10.1007/BF02358078

Shock, C. C., Holmes, Z. A., Strieber, T. D., Eldredge, E. P., \& Zhang, P. (1993). The effect of timed water stress on quality, total solids and reducing sugar content of potatoes. Am. Potato J., 70(3), 227-241. http://dx.doi.org/10.1007/BF02849311

Van Heemst, H. D. J. (1986). The distribution of dry matter during growth of a potato crop. J. Potato Res., 28(1), 55-66. http://dx.doi.org/10.1007/BF02361981

Wurr, D. C. E. (1974). Effect of seed size and spacing on the yield and grading of two main crop potato varieties. J. Agric. Sci., Camb, 82, 37-52.

Wurr, D. C. E., \& Allen, E. J. (1974). Some effect of planting density and variety on the relationship between tuber size and tuber dry-matter percentage in potatoes. J. Agric. Sci., Camb, 82, 227-252.

Yuan, B. Z., Nishiyama, S., \& Kang, Y. (2003). Effect of different irrigation regimes on the growth and yield of drip-irrigated potato. Agric. Water Manage, 63, 153-167. http://dx.doi.org/10.1016/S0378-3774(03)00174-4 